\title{
Yam Cropping System in Cote d'Ivoire: Current Practices and Constraints
}

\section{Amani Michel Kouakou, PhD}

National Centre for Agronomic Research (CNRA), Food Crops Research Station (SRCV), Root and Tuber Crops Program, Côte d'Ivoire

\section{Guy Fernand Yao, PhD}

National Centre for Agronomic Research (CNRA), Central Laboratory for Soils, Waters and Plants (LCSEP), Sustainable Soil Management and Water Control Program, Côte d'Ivoire

\section{Konan Evrard Brice Dibi, PhD}

National Centre for Agronomic Research (CNRA), Food Crops Research

Station (SRCV), Root and Tuber Crops Program, Côte d'Ivoire

\section{Adolphe Mahyao, PhD}

National Centre for Agronomic Research, Research Station of Gagnoa, Agrarian Systems and Sustainable Development Program, Côte d'Ivoire

\section{Antonio Lopez-Montes, PhD}

International Trade Centre (ITC),

Addison House International Trade Fair Center, FAGE, Accra, Ghana

\section{Brice Sidoine Essis, PhD}

\section{Boni N'zue, PhD}

National Centre for Agronomic Research (CNRA), Food Crops Research

Station (SRCV), Root and Tuber Crops Program, Côte d'Ivoire

\section{Brou Kouamé, PhD}

National Centre for Agronomic Research (CNRA), Central Laboratory for Soils, Waters and Plants (LCSEP), Sustainable Soil Management and Water Control Program, Côte d'Ivoire

\section{Patrick Olusanmi Adebola, PhD}

International Institute of Tropical Agriculture (IITA), Ibadan, Nigeria

Doi:10.19044/esj.2019.v15n30p278 URL:http://dx.doi.org/10.19044/esj.2019.v15n30p278

Abstract

Yam is the first food crop in Côte d'Ivoire. It is being cultivated under a traditional technique system with low output. Detailed profiling of the current practices and opportunities for improvement is essential to increase the 
benefits of yam for food security and income in the country. This study diagnosed the current practices, constraints, and requirements in order to gain insight on the yam cropping system for research and development in Côte d'Ivoire. The surveys were conducted in seven (7) regions in the main yam production area. Groups of 60 producers per region were investigated. Individual surveys were also conducted on-farm, particularly for diagnosing the physical environment and yam-based production systems. As results, yambased production systems are characterized by mixed cropping (cassava, corn and vegetable crops) and/or rotation with various other crops (rice, groundnut, vegetable crops, ...). Preferred plots for yam cultivation are forest, savannah or fallow areas. The major constraints in yam cultivation were the effects of environmental stresses, labor scarcity, pest damage, tuber and seed storage difficulties as well as the low market value of yam. The most cultivated yam varieties are Bètè-Bètè and Florido for Dioscorea alata and Lokpa for Dioscorea rotundata. The cropping system, the species and varieties vary according to the region, the topo sequence and the type of soil. Knowledgebuilding that take into account constraints related to yam cultivation, for each production area, can serve as guidance for variety breeding and cultivation environment redefinition.

Keywords: Yam, Cropping systems, Land use, Cultivation environment, Côte d'Ivoire

\section{Introduction}

Yam (Dioscorea spp) is a tuber crop cultivated in the tropical and subtropical areas of Africa, the Caribbean, Oceania and South Asia by smallholders. It is the staple food of more than 300 million people worldwide because of its high nutritional value (Asiedu and Sartie, 2010; Cornet, 2015; Alabi et al., 2019). Yam plays a very important role in food security and livelihood systems for at least 60 million people in West Africa. It is mainly cultivated in the secondary savannah and the Southern Guinea savannah (FAO, 1997 and 1999; Chukwu et Ikwelle, 2000). About 67.31 million tons of yam (that is, $92 \%$ of world production) are produced annually on 7.96 million hectares in West Africa, mainly in five countries, namely Benin, Côte d'Ivoire, Ghana, Nigeria and Togo (Faostat, 2019). Nigeria is the largest producer and alone accounts for about $66 \%$ of world production, followed in third position by Côte d'Ivoire, where yam is the largest food crop by volume, with an annual production of around 7.148 million tons (Faostat, 2019).

Yam is the most important source of calories in Côte d'Ivoire and is one of the top three contributors in Benin and Ghana, also making a substantial contribution in terms of protein to the diet (Dibi et al., 2014). Yam is increasingly becoming a source of income (Doumbia et al., 2006). In Côte 
d'Ivoire, yam production is mainly located in the northeastern, central and eastern parts of the country, above the 8th parallel north, where it is a staple food for populations (Doumbia et al., 2006; N'Goran et al., 2007). However, yam production, in the South of the country, as a food crop supporting the creation of new coffee and cocoa plantations is far from negligible (Doumbia et al., 2006). Despite this important production, yields are below the potential of this crop. The attained yield ranges from 8 to 12 t/ha (Ettien et al., 2003; N'Goran et al., 2007), while the potential is around 65 t/ha (Kowal and Kassam, 1978; FAO, 1999).

Number of factors contributed to the huge yield gap in yams. The most important are yield gap contributor including (i) the scarcity and high cost of quality yam seeds; (ii) losses incurred during harvest and post-harvest; (iii) low soil fertility; (iv) lack of robust varieties adapted to agro-ecological environments of the savannah under climatic constraints; (v) increasing pressure of diseases and pests; (vi) low potential of yam markets for ware and seed yam (vii) limited opportunities for smallholders, particularly women, in terms of yam production and marketing, and (viii) limitation of current breeding capacities that can help develop both resistant and nutritious yam varieties (Cornet, 2004; Ampofo et al., 2010).

Besides, the traditional cropping system based on the long fallow, slash-and-burn shifting cultivation (Ndabalishye, 1995; Doumbia, 1998) and the almost exclusive use of landraces, is unproductive and depletes natural resources (Ettien et al., 2003; N'Goran et al., 2007). Such cropping systems, also extensive, unfortunately provide low yields ( 9 t/ha for the species Dioscorea rotundata and $12 \mathrm{t} / \mathrm{ha}$ for the species Dioscorea alata).

This study aimed at profiling the current yam production practices for a further redefinition of yam cultivation environments in Côte d'Ivoire that better support the research and development effort for the crop in the country.

\section{Methodological approach \\ Selection of study areas}

The approach adopted for a judicious selection of regions, consisted in identifying the pilot sites based on the criteria "large area of yam production in Côte d'Ivoire" and "agro-ecological location". Thus, based on previous works conducted (Doumbia et al., 2006), seven (7) major regions of the yam production basin in Côte d'Ivoire (figure 1 and table 1) were selected. These were the Poro (Korhogo), Tchologo (Ferkessédougou), Hambol (Katiola), Gontougo (Bondoukou), Boukani (Bouna), Gbèkê (Bouaké) and Gôh (Gagnoa) regions.

\section{Surveys}

This study was conducted using the agronomic diagnosis approach (Ferraton et al., 2002). By a systemic approach, it allows a global 
understanding of the functioning of agriculture in a given region. This consists in moving from the general to the particular and in precisely placing yam cultivation in relation with the context of local agriculture. The main levels of organization of the rural environment (Bedu et al., 1987; Jouve, 1992) were considered. They included the yam production area, the production regions and departments and the village and/or encampments. Two types of surveys were conducted, namely, group surveys and individual surveys. Group surveys were carried out on the basis of interviews and discussions during participatory workshops involving local government officials, extension agents, farmers (producers), transporters and traders. Individual surveys were conducted at the farm level based on interviews. In each region, 2 villages were selected. A sample of 30 producers was selected per village. A total of 420 producers were interviewed for the 7 regions. The surveys were semistructured in order to fully give the opportunity to the interlocutor to express concerns not planned by the study.

\section{Data collected and analysis}

Data collection was mainly done by observing the environment and conducting surveys. For group surveys, each working group provided, from a base map of the production region and a questionnaire, the following information's: (i) the dominant types of soils, (ii) accessibility by road, (iii) the yam cropping systems, (iv) the dominant species of yam and all other species, (v) the main challenges in yam production and (vi) the names of dominant yam varieties and intercrops. Individual surveys focused on: (i) the yam production systems practiced by smallholders, (ii) the socio-demographic characteristics of the farmer, (iii) the importance of yam cultivation and the cropping systems practiced, (iv) the farm management (farm characteristics, cropping practices), and (v) the major constraints related to the cultivation.

Data analysis was based on descriptive statistics with STATA software. The $\mathrm{Chi}^{2}$ test and the Monte Carlo method were used to compare the different proportions. In case of significant differences, the Marascuilo procedure was used to form homogeneous groups (Sunanda et al., 2016). ArcGIS 10.0.1 and MapInfo 11 software were used for the development of thematic maps. WockWare 15 software enabled the conversion of DMS (Degrees, Minutes and Seconds) geographic coordinates into UTM (Universal Transverse Mercator) for better projection of production regions into the cartographic systems. Paint software made it possible to finalize the maps. Thematic maps were developed using spatial interpolation methods, and also using the nearest neighbor method of ArcGis (Assign Proximity) software. A codification of the different parameters had been made beforehand. 


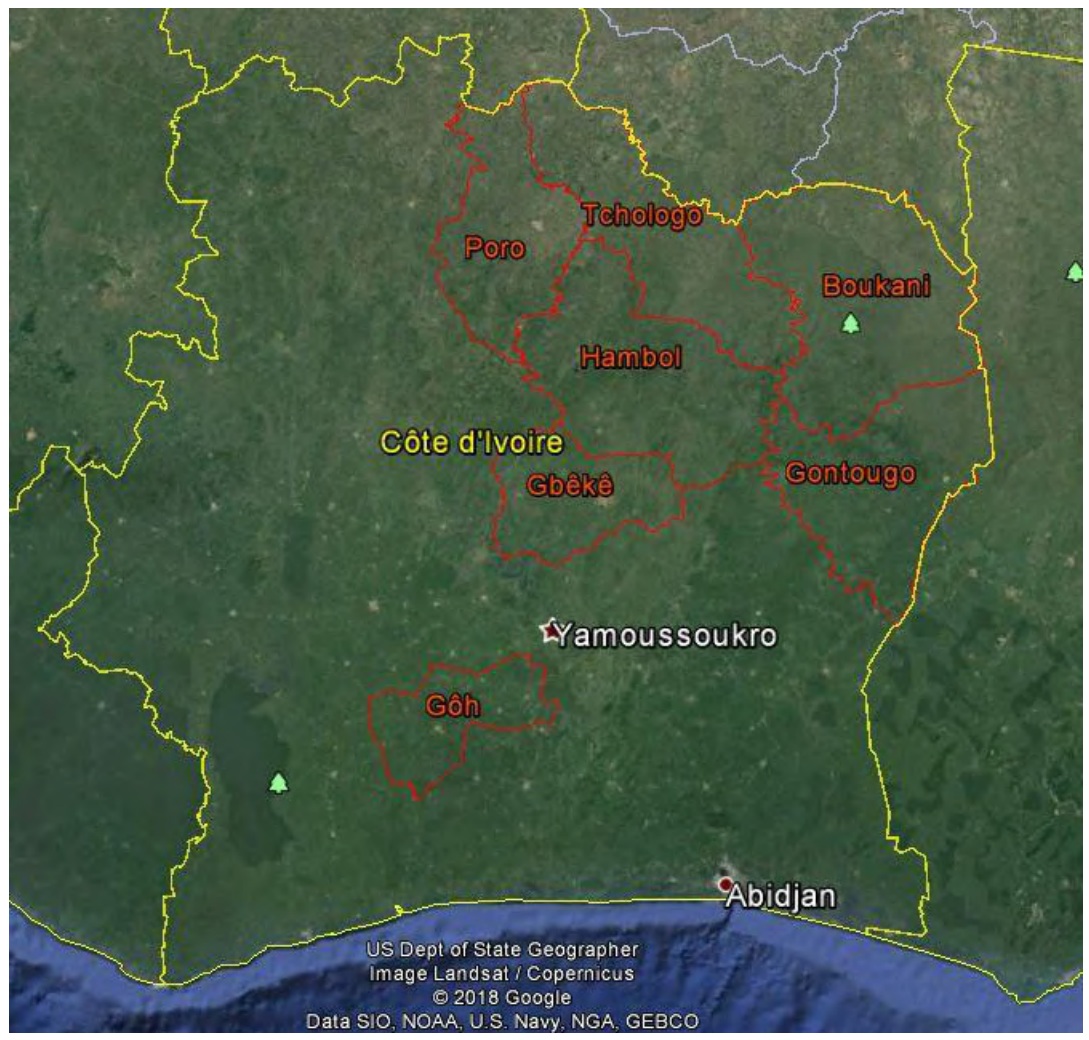

Figure 1. Study regions of the yam production basin in Côte d'Ivoire

Table 5. Regions, departments and study sites according to yam production areas

\begin{tabular}{cccc}
\hline $\begin{array}{c}\text { Production } \\
\text { areas }\end{array}$ & Regions & Departments & Survey sites \\
\hline \multirow{2}{*}{ North } & Poro & Korhogo, Dikodougou & Poundia, Nerkéné \\
\cline { 2 - 4 } North-East & Tchologo & Ferkessédougou & Kolon \\
\cline { 2 - 4 } & Boukani & Bouna, Nassian (Sominassé) & Siriki-Bango, Ondéfidouo \\
\hline \multirow{2}{*}{ Center } & Hambol & Kondoukou (Sorobango), Tanda & Tambi, Ahibongo \\
\cline { 2 - 4 } & Gbèkê & Bouaké, Sakassou & N'Gorla, Taggbonon-Bambarasso, \\
Kest-central & Gôh & Gagnoa & Kpêtébonou, Languibonou \\
\hline Total & 07 & 13 & Ony-Babré \\
\hline
\end{tabular}

\section{Results}

Yam species and varieties cultivated in Côte d'Ivoire

The frequency calculation is based on the proportions of producers who cited the variety in first, second or third place according to the importance of production (table 2, figures 2 and 3). A larger number of producers (26.89\%) cited Bètè-Bètè in first place, then $25.94 \%$ of producers cited Florido in second place and $18.27 \%$ of producers cited Lokpa in third place. It 
appeared that the three varieties Bètè-Bètè and Florido of $D$. alata species and Lokpa of $D$. rotundata species were the most cultivated yam varieties in Côte d'Ivoire. The results of the surveys also revealed the cultivation of $D$. cayenensis variety Kangba (0.98\%), in the Central region. It should also be noted the presence of a very wide range of yam varieties poorly cultivated by producers. Moreover, three improved varieties, namely Florido, Azaguié and C18 (D. alata), were listed. Three yam species (D. alata, D. rotundata and D. cayenensis) are cultivated in Côte d'Ivoire (table 2).

Table 6. Frequency of yams varieties cultivated in all regions investigated in Côte d'Ivoire

\begin{tabular}{|c|c|c|c|c|}
\hline Varieties & Species & $\begin{array}{c}1^{\text {st }} \\
\text { position }\end{array}$ & $2^{\text {nd }}$ position & $3^{\text {rd }}$ position \\
\hline Bètè-Bètè & D. alata & 26.89 & 23.69 & 17.34 \\
\hline Kponan & D. rotundata & 16.87 & 3.74 & 2.48 \\
\hline Krenglè & D. rotundata & 14.18 & 9.98 & 10.22 \\
\hline Wacrou & D. rotundata & 10.76 & 0.50 & 0.62 \\
\hline Lokpa & D. rotundata & 8.80 & 10.97 & 18.27 \\
\hline Florido & D. alata & 8.31 & 25.94 & 23.53 \\
\hline Azaguie & D. alata & 5.62 & 2 & 0.31 \\
\hline Anader & D. alata & 2.2 & 1.5 & 0.31 \\
\hline $\mathrm{N}^{\prime} \mathrm{Za}$ & D. alata & 2.2 & 5.99 & 3.41 \\
\hline Kangba & D. cayenensis & 0.98 & 1 & 4.33 \\
\hline Sopian & D. alata & 0.73 & 2.74 & 2.48 \\
\hline $\begin{array}{l}\text { Kpassadjo or } \\
\text { kpalkpadjo }\end{array}$ & D. cayenensis & 0.73 & 1.5 & 2.3 \\
\hline Logoperi & D. rotundata & 0.49 & 1.25 & 3.1 \\
\hline Cameroun & D. alata & 0.24 & 0.5 & 1.55 \\
\hline Gnan & D. rotundata & 0.24 & & \\
\hline Sopere & D. rotundata & 0.24 & & \\
\hline Cocomsene & D. cayenensis & 0.24 & & \\
\hline Kpongo & D. rotundata & 0.24 & & \\
\hline Pahinte & D. rotundata & 0.24 & 2.24 & \\
\hline Trela & D. rotundata & 0.24 & & \\
\hline Américain or Florido & D. alata & & 0.5 & 0.31 \\
\hline Assawa & D. rotundata & & 1.5 & 0.62 \\
\hline Brésil or C18 & D. alata & & 0.25 & \\
\hline Koudjan & D. rotundata & & & 0.31 \\
\hline Cocoassie & D. rotundata & & 0.25 & \\
\hline Pahinte & D. rotundata & & 0.25 & 4.02 \\
\hline Soule Kouam & D. cayenensis & & & 0.31 \\
\hline Bolodja & D. rotundata & & 0.75 & 0.62 \\
\hline Djinangbo & D. rotundata & & 0.25 & 1.24 \\
\hline
\end{tabular}

It appeared that two yam species, namely $D$. rotundata and D. alata, are exclusively cultivated in the Poro, Tchologo, Hambol and Boukani production regions. Whereas, all the three species, D. cayenensis, D. rotundata and $D$. 
alata, are cultivated in the Gontougo, Gbêkê and Goh production regions, with a higher proportion in the Gontougo and Gbêkê regions (figure 2).

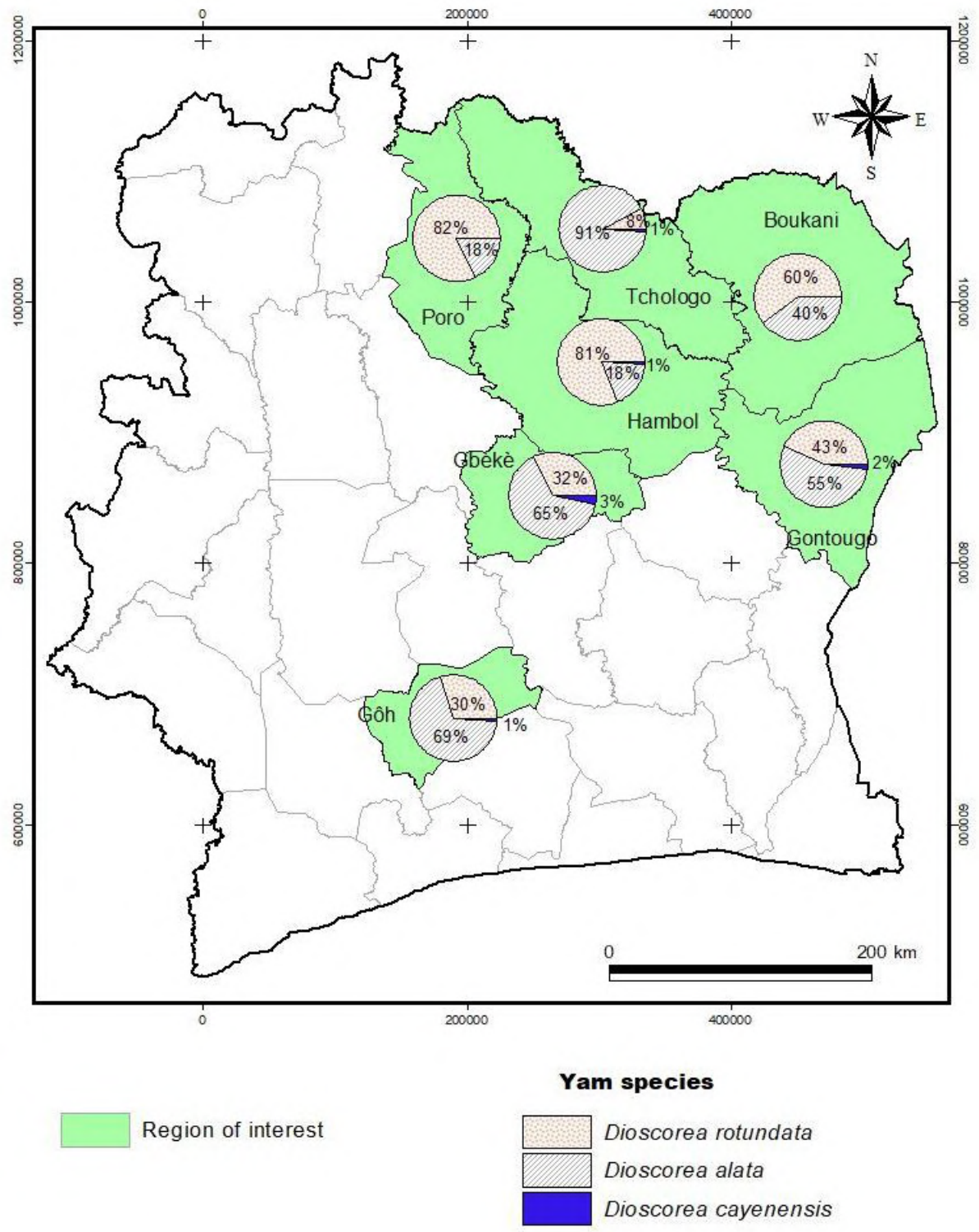

Figure 2. Importance of yam species cultivated in the yam production areas

The distribution of the yam varieties cultivated (figure 3), showed that the varietal groups (Kponan or Wacrou, Krengle and Koudjan or Pahinté) of the $D$. rotundata species were the most cultivated and came most time at first position in the Northern (Poro and Tchologo) and Northeastern (Gontougo and Boukani) regions, and Florido or Américain and C18 or Anader of the D. alata species were found at the second position. 


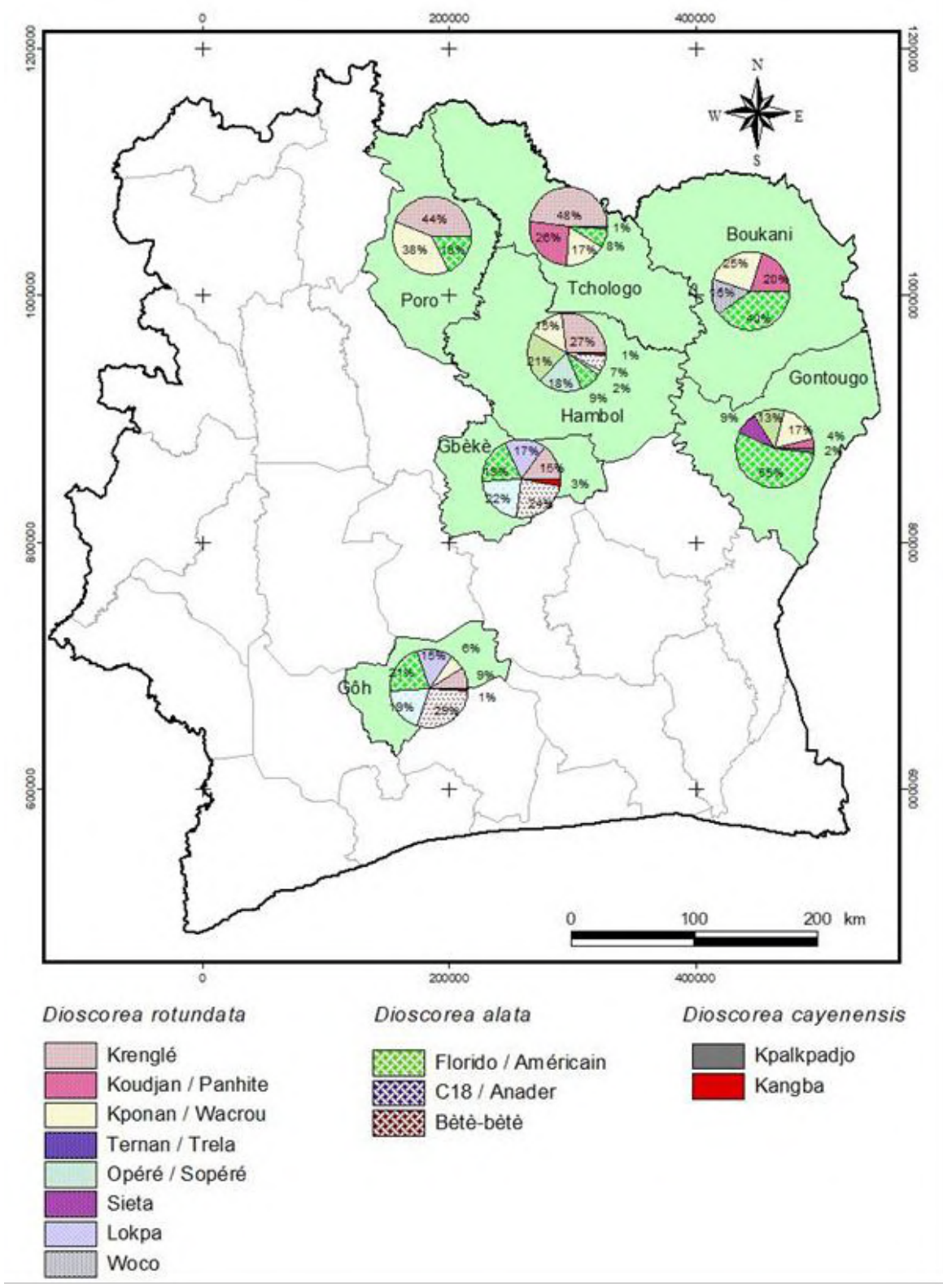

Figure 3. Yam varieties cultivated in yam production areas

Conversely, for the Central (Hambol and Gbêkê) and West-central (Gôh) production areas, the varieties Bétè-bètè, Florido or Américain and C18 or Anader, of D. alata were the ones cultivated in order of importance and listed in first position. It also appeared that for these two large regions, only Lokpa and Krengle were the two varieties of $D$. rotundata exclusively cultivated. In addition, it appears from these analyses that two (2) varieties 
from the $D$. cayenensis group, in particular Kpassadjo or kpalkpadjo in the North-East (Gontougo) and Kangba in the Centre (Gbêkê), are also grown.

Figures 4 and 5 presents the distribution of varieties with regard to the soil landscape and the topographic positions. The water yam varieties occupied the plateau topographic segments and/or upper hillside, while white yam varieties are cultivated in lower hillside topographic position. However, in the West-central region (Gôh), regardless of the soil landscape, no white yam (D. rotundata) variety was found.

\section{Agronomic characteristics of farms, cropping systems and cropping practices}

The characteristics of yam producers' household farms in Côte d'Ivoire, as well as the cropping systems and farming practices, are shown in tables 3 and 4, respectively. The analysis showed that yam producers had farms of varying sizes. These sizes varied from 0.02 to 30 ha for yam and 0.01 to 42 ha for other commodities. The average sizes were 2.62 ha for yam; 7.10 ha for other crops and 7.91 ha for fallow land (table 3).

Concerning the characteristics of yam-based cropping systems practiced in all the production areas in Côte d'Ivoire (table 4), the most significantly crops combined with yam, in order of importance, were the following: corn $(74.94 \%)$, cassava $(74.28 \%)$ and vegetable crops $(56.10 \%)$. Crops most grown in rotation with yam were significantly groundnuts (98.31\%), vegetable crops $(96.30 \%)$, cassava $(93.06 \%)$, corn $(92.52 \%)$, rainfed rice $(87.75 \%)$, yam $(78.31 \%)$ and millet $(76 \%)$. Thus, the leading rotational crops were essentially groundnuts and vegetable crops.

The rotation cycles varied according to the crops (3.85 years for rainfed rice, 1.81 years for groundnut, 1.20 years for vegetable crops, 1.72 years for cassava, 1.82 years for corn and 1.30 years for yam. Millet $(17.07 \%)$, sorghum $(9.53 \%)$ and fonio $(2 \%)$ were rarely combined with yam and the rotation cycles were longer (4 to 6 years). The average fallow duration ranged from 3.6 to 5.66 years. Yam succeeded to yam in some rotations.

\section{Local knowledge and rural strategies for the perception of soil fertility for the choice of the land for yam cultivation}

The endogenous criteria of plot choice by farmers for yam cultivation are shown in table 5. These criteria essentially included the type of vegetation, the type of preceding crop and the presence of perennial crops. Concerning the type of vegetation, forests were significantly the first chosen $(53.86 \%)$ followed by savannahs (40.68\%). Fallow (42.36\%) and perennial crops $(35.45 \%)$ are significantly the most preferred as preceding crops.

For soil type, the textural aspect of the soil (sandy or clayey, $47.62 \%$ ) is the most determinant factor followed by the surface condition (gravelly or 
non-gravelly, 36.05\%). However, the color of the soil and the topographic position were less important. Swampy soils and areas previously used for annual crops were less preferred by farmers for yam cultivation.

\section{Constraints encountered in yam cultivation}

The constraints encountered in yam cultivation described by the producers are presented in table 6 . At the vegetative stage, the most important significant constraints were firstly the effects of rain/water supply through the instability of the dry and rainy seasons disrupting the crop calendar $(37.59 \%)$, then labor scarcity (21.99\%). Thirdly, there is work arduousness (11.35), lack of financial resources $(9.46 \%)$, pest damage $(6.85 \%)$ and decline of soil fertility $(6.15 \%)$. The least frequent constraints were land pressure, plant diseases, weed pressure and poor seed quality.

At the harvest and post-harvest stages, the significant major constraints were pest damage (22.28\%), tuber and seed rot (18.75\%) and yam storage difficulties $(15.76 \%)$ followed by environmental stresses $(11.96 \%)$. Low productivity of varieties $(7.61 \%)$ and the need of training for the producers $(7.34 \%)$ were also mentioned by producers. At the market level, the difficulties expressed were firstly the low sales price $(50.21 \%)$ and secondly the lack of adequate means for yam transportation (17.17\%). In a smaller proportion, the difficulties for yam sellers to access yam fields $(8.58 \%)$, price fluctuation $(8.58 \%)$ and the scarcity of purchasers $(5.58 \%)$ were also listed. 


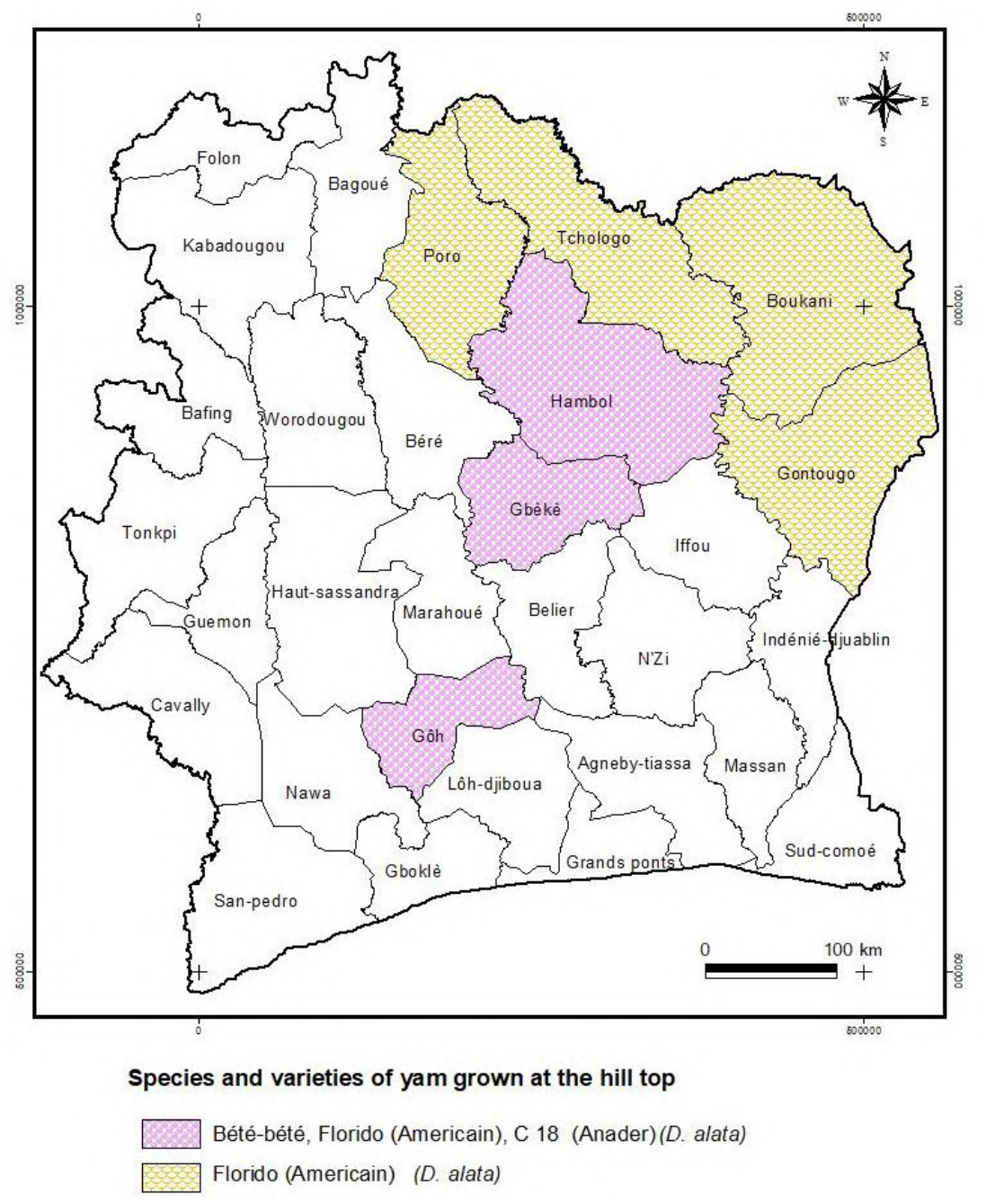

Figure 4. Yam species and varieties cultivated on plateau topographic position in the study areas 


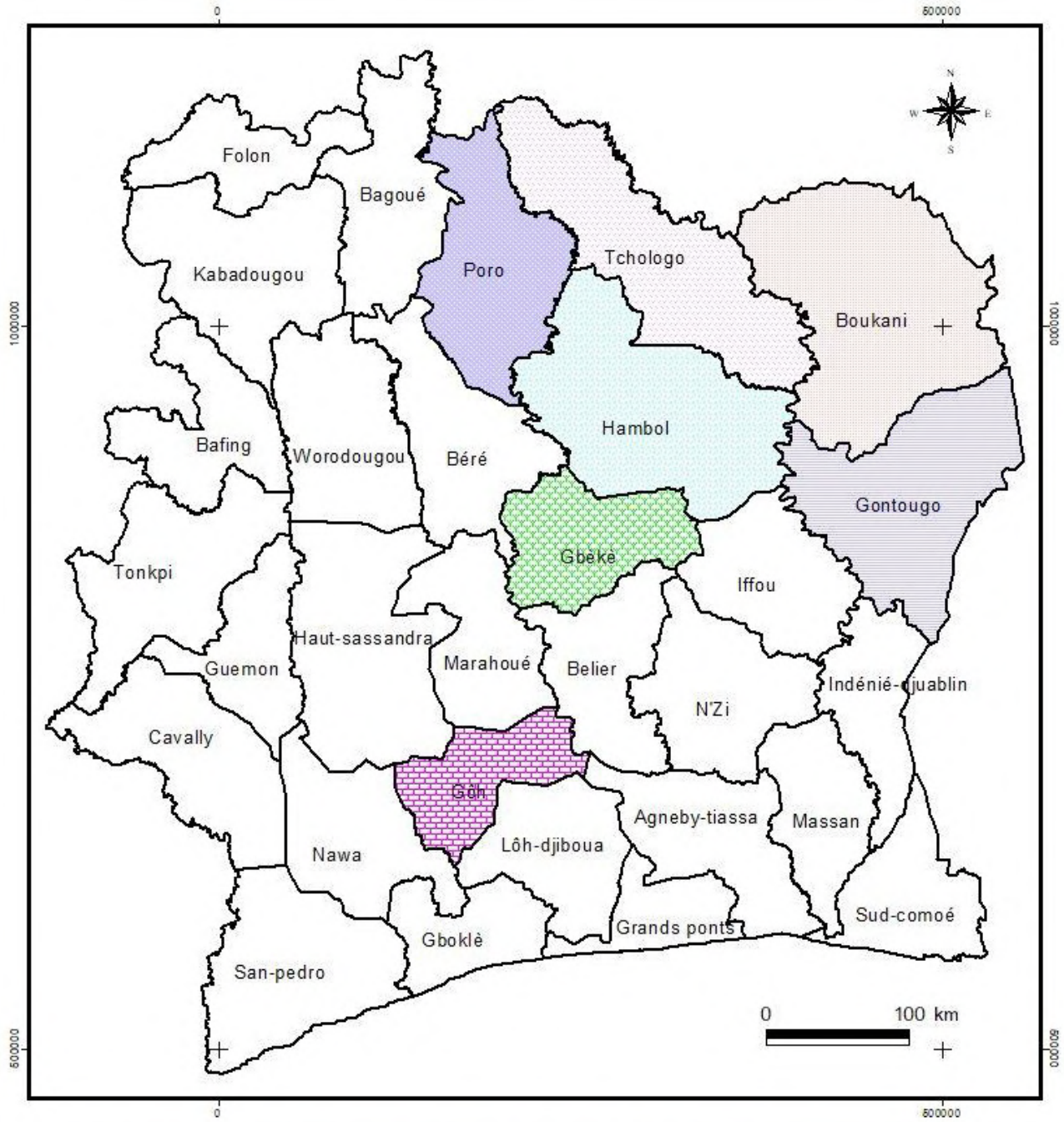

Species and varieties of yam grown at the bottom of the slope
Kponan (Wacrou), Koudjan (Pahinté), Woco (D. rotundata)
Kponan (Wacrou), Trela (Ternan), Kpalkpadjo (Kpassadjo), Sieta, Koudjan (Pahinté) (D. rotundata) Krenglé et Kponan (Wacrou) $\quad$ (D. rotundata)
Krenglé, Opéré (Sopéré), Trela (Ternan), Kponan (Wacrou) (D. rotundata) ; Kangba (D. cayenensis) Krenglé, Wacrou (Kponan), Koudjan (Panhite) (D. rotundata); Kpalpkadjo (Kpassadjo)(D. cayenensis) Lokpa, Krenglé (D. rotundata) ; Kangba (D. cayenensis)
Lokpa, Krenglé, Kponan (WacrouYD. rotundata) ; Kangba (D. cayenensis)

Figure 5. Yam species and varieties cultivated on lower hillside topographic position in yam production areas 
Table 7. Characteristics of yam producers' household farms

\begin{tabular}{ccccc}
\hline Variables (units) & Minimum & Maximum & Average & $\begin{array}{c}\text { Standard } \\
\text { deviation }\end{array}$ \\
\hline Surface areas of crops (ha) & 0.01 & 42 & 7.10 & 7.23 \\
Surface areas of yam plots (ha) & 0.02 & 30 & 2.62 & 3.89 \\
Surface areas of fallows (ha) & 0 & 99 & 7.91 & 9.34 \\
Number of cropping cycles & 1 & 9 & 1.56 & 1.09 \\
\hline
\end{tabular}

Table 8. Yam-based cropping systems in all production areas

\begin{tabular}{|c|c|c|c|c|c|c|c|c|}
\hline \multirow{2}{*}{$\begin{array}{c}\text { Variables } \\
\text { Crops }\end{array}$} & \multirow{2}{*}{$\begin{array}{c}\begin{array}{c}\text { Crop } \\
\text { combination } \\
(\%)\end{array} \\
\text { Yes }\end{array}$} & \multirow{2}{*}{$\begin{array}{c}\begin{array}{c}\text { Crop } \\
\text { rotation } \\
(\%)\end{array} \\
\text { Yes }\end{array}$} & \multicolumn{2}{|c|}{$\begin{array}{c}\text { Rotation } \\
\text { cycle } \\
\text { (years) }\end{array}$} & \multicolumn{4}{|c|}{$\begin{array}{c}\text { Fallow duration } \\
\text { (years) }\end{array}$} \\
\hline & & & Min & Max & Average & Min & Max & Average \\
\hline Yam & - & $78.31 \mathrm{a}$ & 0 & 10 & 1.30 & 0 & 30 & 4.07 \\
\hline Cassava & $74.28 \mathrm{a}$ & $93.06 \mathrm{a}$ & 0 & 15 & 1.72 & 0 & 15 & 4.71 \\
\hline $\begin{array}{l}\text { Rainfed } \\
\text { rice }\end{array}$ & 7.76de & $87.75 \mathrm{a}$ & 0 & 12 & 3.85 & 1 & 10 & 3.6 \\
\hline Corn & $74.94 \mathrm{a}$ & $92.52 \mathrm{a}$ & 1 & 15 & 1.82 & 0 & 20 & 4.22 \\
\hline Groundnut & $27.94 \mathrm{bcd}$ & $98.31 \mathrm{a}$ & 0 & 15 & 1.81 & 0 & 20 & 3.48 \\
\hline Millet & $17.07 \mathrm{cde}$ & $76 a$ & 1 & 15 & 5.55 & 0 & 15 & 5.66 \\
\hline Sorghum & $9.53 \mathrm{cde}$ & $22.22 b$ & 1 & 15 & 4.08 & - & - & - \\
\hline Fonio & $2.00 \mathrm{e}$ & - & - & - & - & - & - & - \\
\hline $\begin{array}{l}\text { Vegetable } \\
\text { crops }\end{array}$ & $56.10 \mathrm{ab}$ & $96.30 \mathrm{a}$ & 1 & 4 & 1.20 & 0 & 8 & 3.43 \\
\hline Perennial & $35.25 b c$ & - & - & - & - & - & - & - \\
\hline
\end{tabular}

Frequencies followed by the same letter are not significantly different $(P \leq 0.05)$

Table 9. Endogenous sol selection criteria for yam cultivation

\begin{tabular}{|c|c|c|}
\hline $\begin{array}{c}\text { Endogenous } \\
\text { selection } \\
\text { criteria }\end{array}$ & Modalities & $\begin{array}{c}\text { Importance } \\
\text { Frequencies } \\
(\%)\end{array}$ \\
\hline \multirow{4}{*}{$\begin{array}{l}\text { Vegetation } \\
\text { type }\end{array}$} & Forests & $53.86 \mathrm{a}$ \\
\hline & Savannahs & $40.68 b$ \\
\hline & Swamps & - \\
\hline & Other & $5.45 \mathrm{c}$ \\
\hline \multirow{4}{*}{$\begin{array}{l}\text { Preceding } \\
\quad \text { crop }\end{array}$} & Perennial crops & $35.45 \mathrm{a}$ \\
\hline & Annual crops & $19.02 \mathrm{~b}$ \\
\hline & Fallow & $42.36 \mathrm{a}$ \\
\hline & Other & $3.17 \mathrm{c}$ \\
\hline \multirow{4}{*}{ Type de sol } & $\begin{array}{l}\text { Textural appearance of the soil (sandy or } \\
\text { clayey) }\end{array}$ & $47.62 \mathrm{a}$ \\
\hline & $\begin{array}{l}\text { Surface condition (gravelly or non- } \\
\text { gravelly) }\end{array}$ & $36.05 b$ \\
\hline & Soil color (red, black or greyish) & $15.42 \mathrm{c}$ \\
\hline & $\begin{array}{l}\text { Topographic position (plateau, middle } \\
\text { hillside or lower hillside) }\end{array}$ & $0.91 d$ \\
\hline
\end{tabular}

Frequencies of each criteria followed by the same letter are not significantly different

$$
(P \leq 0.05)
$$


Table 10. Constraints and their importance to yam cultivation in Côte d'Ivoire

\begin{tabular}{|c|c|c|}
\hline Stages & Constraints & $\begin{array}{c}\text { Importance } \\
\text { frequencies } \\
(\%)\end{array}$ \\
\hline \multirow{10}{*}{ Vegetative stage } & Rain/water supply & $37.59 \mathrm{a}$ \\
\hline & Labor scarcity & $21.99 b$ \\
\hline & Work arduousness & $11.35 \mathrm{c}$ \\
\hline & Lack of financial resources & $9.46 \mathrm{~cd}$ \\
\hline & Pest damage & $6.85 \mathrm{~cd}$ \\
\hline & Soil fertility decline & $6.15 \mathrm{~cd}$ \\
\hline & Land pressure & $3.78 \mathrm{de}$ \\
\hline & Plant diseases & $0.47 \mathrm{e}$ \\
\hline & Adventitious plant pressure & $0.24 \mathrm{e}$ \\
\hline & Poor seed quality & $0.24 \mathrm{e}$ \\
\hline \multirow{6}{*}{ Post-harvest } & Pest damage & $22.28 \mathrm{a}$ \\
\hline & Tuber and seed rot & $18.75 \mathrm{ab}$ \\
\hline & Yam storage difficulties & $15.76 \mathrm{ab}$ \\
\hline & Environmental stresses & $11.96 \mathrm{bc}$ \\
\hline & $\begin{array}{c}\text { Low productivity of } \\
\text { varieties }\end{array}$ & $7.61 \mathrm{c}$ \\
\hline & Need for training & $7.34 \mathrm{c}$ \\
\hline \multirow{5}{*}{ Marketing } & Low sales price & $50.21 \mathrm{a}$ \\
\hline & $\begin{array}{c}\text { Lack of yam transportation } \\
\text { means }\end{array}$ & $17.17 \mathrm{~b}$ \\
\hline & $\begin{array}{l}\text { Difficult access of } \\
\text { purchasers to farms }\end{array}$ & $8.58 \mathrm{c}$ \\
\hline & Price fluctuation & $8.58 \mathrm{c}$ \\
\hline & Purchaser scarcity & $5.58 \mathrm{c}$ \\
\hline
\end{tabular}

Frequencies of each constraint in a stage followed by the same letter are not significantly different $(P \leq 0.05)$

\section{Discussion}

This study diagnosed the current status of cropping practices and the yam cultivation environments in Côte d'Ivoire. Many factors were involved in the yam production and these varied within and among regions. Dioscorea alata and Dioscorea rotundata were the two main species of yam cultivated in Côte d'Ivoire, with about thirty varieties listed. The production is dominated by the landraces: Bêtê-Bêtê for $D$. alata and Lokpa, Kponan, Krenglè for $D$. rotundata. These results are consistent with the findings of Doumbia et al., (2006), Kouakou et al., (2012), Bakayoko et al., (2017), who also noted the predominance of landraces and the low proportion of improved varieties represented by Florido, Azaguié and C18 of the D. alata species. The importance of yam species and varieties varied across regions. In Central Côte d'Ivoire, the D. alata species is predominant, whereas in the North and Northeast the D. rotundata species is most cultivated (Orkwor and Asadu, 1998 and Doumbia et al., 2006). However, this study showed that the D. alata species, particularly the variety Florido, is also well cultivated in the Northeastern 
regions (Bouna). This is opposed to the results of). The varieties Bètè-bètè and Florido which are D. alata, were the most cultivated in the West-central area which is not favorable or suitable to the D. rotundata (Doumbia et al, 2006). Indeed, the West-central area which is a humid forest zone with a high pressure of diseases has become a new yam production area, following the migration of people from the Center and the North to this region (Doumbia et $a l, 2006)$. But the virus diseases limit the development of the varieties of Dioscorea rotundata.

General confusion were noticed on the nomenclature of yam varieties cultivated by producers. For example, the improved varieties C18 and Florido are called Cameroun or Americain by the farmers. The works of Kouakou (2010) and Kouakou et al. (2015) gave agro-morphological criteria for the identification of varietal groups for D. alata.

The results relating to the agronomic characteristics of farms confirmed the smallness of yam-cultivated surface areas with an average of 2.5 hectares for all the areas of the production basin. These results corroborate the works of Floquet et al. (2012) and Dibi et al. (2014), which showed that such smallness of surface areas could be explained by the scarcity and high cost of seeds at the time of planting. Moreover, the lack of labor might also limit the will of producers to have large surface areas. Indeed, yam cultivation is entirely manual, despite the existing opportunities for its mechanization (Doumbia et al., 2006; Dibi et al., 2014).

Yam is usually grown in mixed crop with other crops. Rice and cassava are the most common combinations in the savannah area. In the forest area, cocoa and coffee were planted simultaneously with yam. Yam always leads rotation. Fallows period becomes shorter remaining below ten (10) years. Yam often comes back to rotation after two (2) years, in some cases, with quadrennial and triennial rotations in cropping systems (Le Buanec and Jacob, 1981; Kalms and Chabalier, 1981; Yeboua, 1990; Doumbia, 1998). This is a very substantial reduction compared to the ten (10) years generally indicated by some authors (Pieri, 1989; Dumont, 1997; Carsky et al., 1998a). Indeed, the long duration of fallow is justified by the fact that despite the importance of yam, traditional methods of production continue to be used, such as cultivation without input, leading to rotation because of its high nutrient requirements, particularly nitrogen and potassium (with average input estimated at $3-5 \mathrm{~kg} \mathrm{~N}, 0.4-0.5 \mathrm{~kg} \mathrm{P}, 3-5 \mathrm{~kg} \mathrm{~K}$ per ton of fresh material produced. As indicated by the numerous works of Degras (1986), Vernier (1998), Carsky et al. (1998b), Cornet et al. (2014), Cornet (2015), Diby et al. (2009), Diby et al. 2012) and Hgaza et al. (2012), soil fertility remains one of the main constraints encountered in traditional cultivation. 
This study also revealed that yam can be cultivated during two successive cropping seasons on the same soil. However, in such case, greater difficulties of emergence were observed (Maliki 2006, Floquet et al., 2012).

Yam producers have indigenous knowledge that determines their choices for the establishment of the crop. Thus, yam varieties of the D. alata species are found in forest areas or in woodland savannahs, whereas $D$. rotundata varieties are established in savannah areas. Degras (1986) has shown that gravelly soils that degrade yam quality, and swampy lands are not suitable for yam cultivation. These notions are well known by producers. In the same environment, soil typology, textural aspect and surface conditions are the most determinant factors for yam producers in the choice of their plot; but the color of the soil and the topographic position were less important for them in this study. However, soil heterogeneity, through its color, is a handicap for the management of its fertility and a constraint in agronomic experiments. Approaches to characterize this variability have been developed previously by Moreau (1990) in the forest zone and Vauclin and Chopart (1991), and Koné and Assa (2008) in the forest-savannah transition area and in the savannah. These authors indicated that the surface horizon of the soil and its color can be used to identify samples with variable aspects. Seubert et al. (1977) and Sanchez et al. (1983), reported the effect of agricultural practices such as clearing or bush fires as sources of this variability. The heterogeneity described by the color of the soil could be explained by the dynamics of water along the toposequence inducing a hierarchy of the color of the ferralitic soils along this one (Koné, 2007).

This study shows that despite their great knowledge of yam cultivation, producers have little knowledge of yam diseases. Indeed, farmers did not give any importance to the diseases as constraints. However, there is evidence that the disease can cause losses of up to $80 \%$ of the crop (Lebot, 2009; Richard et al., 2010). The economic impacts of the major biotic constraints (nematodes, viral diseases and anthracnose) will increase with the intensification of yam production systems, unless resistant varieties and beneficial cropping practices are adopted. Furthermore, from planting to storage, both tubers and yam plants are subject to various attacks. A study conducted by the International Institute of Tropical Agriculture (IITA) in Nigeria found that insects cause more damage to yam in Africa, and beetles are the most important of this group (Lebot, 2009). Also, Goudou-Shina (1995) noted that losses during storage can reach $40 \%$. It is therefore crucial to train farmers on recognition and control of yam diseases and pests.

Producers did not consider the problem of seeds among the first constraints. Though, in the traditional yam production technique, the demand for seed is so high that some producers are forced to reduce cultivated areas. Indeed, 30 to $40 \%$ of the tubers harvested are used as seed (Dibi et al., 2014). 
To this unavailability of planting material, is added the ageing of this planting material. In a study conducted in Benin, Dansi (2003) it is noted that more than $80 \%$ of the varieties used by farmers were inherited from their parents.

Farmers identified the effects of rain supply through the instability of the dry and rainy as the most important significant constraints at the vegetative stage. In fact, environmental stresses through the instability of dry and rainy seasons disrupts the cropping calendar of yam. Thus, despite its resilience, as yam cultivation is rainfed, it is subject to climatic uncertainties. The establishments are more and more delayed and the cropping cycles are reduced, thus limiting yields. Farmers are now aware of this phenomenon despite the traditional considerations attached to it (Bell et al., 2000; Lebot 2009; O'Sullivan et al., 2008; O'Sullivan and Jane Nancy, 2010). These findings are consistent with the work of Sinsin and Kampmann (2010) which showed that it is the decrease of the quantity of water gradually as the temperature increases, coupled with a decrease in the relative humidity of air, which affect the growth of plants. Indeed, an unprecedented rate of degradation of the natural resources of the countries of West Africa were observed during these last decades. In addition, deforestation in the tropics which is caused at $60 \%$ by slash and burn agriculture, directly releases 40 to $50 \%$ of total carbon through biomass burning (FAO, 2002). As a consequence, carbon emissions contribute to the global warming of the earth, which is probably at the root of climate change, characterized inter alia by the seasonal variability of rainfall (rainfall delays and pockets of drought of varying lengths) and floods, followed by biodiversity degradation (Dansi et al., 2013).

Thus, variability in yam yield is generally attributed to soil fertility depletion (Diby et al., 2009), pests and diseases (Coyne et al., 2006), farmers' decisions regarding resource allocation (Nkonya et al., 2005) and their agronomics practices (Mutsaers et al., 1997), or the combinations of these all factors (Samake et al., 2006). In contrast, Ghosh et al. (1988) and Ike and Inoni (2006) consider rainfall delays as one of the main sources of yam production decline. This work corroborates those of Dansi et al. (2013) and Ehounou (2014), showing water requirements for yam cultivation, especially after germination of the crop and then between the fourteenth and twentieth weeks of growth. As a result, the work of Tittonell et al. (2007), have indicated that agronomic management decisions should influence the efficiency of resource use (land, inputs, water, etc.) and therefore the productivity of the crop.

\section{Conclusion}

This study on the identification of current cropping practices and yam cultivation environment, which took place in seven (7) regions of the yam production basin in Côte d'Ivoire, has helped describing the characteristics of 
yam production systems. With average yields still below the potential of the crop, constraints such as virus diseases, unsuitability of the planting material, the poor soil fertility, the post-harvest losses, the traditional cropping systems without inputs and the weeds are the weakness of yam production in Côte d'Ivoire. The constraints having been identified, it remains to take them into account, in order to develop relevant guidance and decision-making tools for variety breeding and cultivation environment redefinition.

Acknowledgements: The authors express their gratitude to the Melinda Bill Gates Foundation for the financing of the AfricaYam Project (Enhancing yam breeding for increased productivity and improved quality in West Africa), the National Center for Agronomic Research (CNRA), the International Institute of Tropical Agriculture (IITA) and partners in West African countries for their support to this study.

\section{References:}

1. Alabi TR, Adebola PO, Asfaw A, DE Koeyer D, Lopez-Montes A, and Asiedu R (2019). Spatial Multivariate Cluster Analysis for Defining Target Population of Environments in West Africa for Yam Breeding. International Journal of Applied Geospatial Research, 10(3), 1-30. doi:10.4018/ijagr.2019070104

2. Ampofo JKO, Kumar Pl and Seal SE (2010). Integrated Crop Management for Sustainable Yam Production. In, Yam Research for Development in West Africa - Working Papers. IITA-BMGF Consultation Documents, IITA. Pp 46-80

3. Asiedu R. and Sartie A (2010). Crops that feed the world 1. Yams: Yams for income and food security. Food Security, 2(4), 305-315. doi:10.1007/s12571-010-0085-0

4. Bakayoko GA, Kouame KF, Boraud NKM (2017). Culture de l'igname au Centre-Est de la Côte d'Ivoire : contraintes, caractéristiques sociodémographiques et agronomiques. Journal of Applied Biosciences, ISSN 1997-5902, 110: 10701-10713

5. Bedu L, Martin C, Knepfler M, Tallec M, Urbino A, Bonnemaire J, Jouve P (1987). Appui pédagogique à l'analyse du milieu rural dans une perspective de développement. Montpellier : CIRAD-DSA, $191 \mathrm{p}$.

6. Bell N, Carslaw N, Creasey D, Derwent R, Heard D, Jenkin M, Lee J, Lewis A, McQuaid J, Pilling MJ, Pascoe S, Saunders S and Seakins P (2000). Development and Applications of a Master Chemical Mechanism. In CMD Annual Report 1999. EUROTRAC-2, International Scientific Secretariat, pp. 72-75.

7. Carsky RJ, Tarawali SA, Becker M, Chicoye D, Tian G and Sauplaga N (1998a). Mucuna-herbaceous cover legume with potential for 
multiple use. In Resource and Crop Management Research Monographs 25. International Institute of Tropical Agriculture, lbadan, Nigeria.

8. Carsky RJ, Wolo N, Manyong VM, Tian G and Asiedu R (1998b). Nutrient Balance Modelling for Design of Sustainable Yam Cropping Systems 14p(ed.). Cotonou, Benin. 1998. ISTRC-AB.

9. Chukwu GO. Ou G.O et Ikwelle MC ou M.C. (2000). Yam: Threats to its sustainability in Nigeria News NRCRI Uudike, P.M.B. Umuahia, Abia State, 17(1): 1-7

10. Cornet D (2015). Influence des premiers stades de croissance sur la variabilité du rendement parcellaire de deux espèces d'igname (Dioscorea spp.) cultivées en Afrique de l'Ouest. Paris, France. L'Institut des Sciences et Industries du Vivant et de l'Environnement (AgroParisTech). 174p.

11. Cornet D, Sierra J, Tournebize R and Ney B. (2014). Yams (Dioscorea spp.) plant size hierarchy and yield variability: Emergence time is critical. European Journal of Agronomy, 55, 100-107. https://doi.org/10.1016/j.eja.2014.02.002 .

12. Cornet D. (2004). Systèmes de cultures associées à base d'igname et gestion des plantes adventices. Revue bibliographique commentée. FSAGx, Gembloux, Belgique.

13. Coyne DL, Tchabi A, Baimey H, Labuschagne N and Rotifa I (2006). Distribution and prevalence of nematodes (Scutellonema bradys and Meloidogyne spp.) on marketed yam (Dioscorea spp.). Field Crops Research 96: 142-150.

14. Dansi A (2003). Les variétés d'ignames cultivées: Savoir-faire paysan au Bénin. Food \& Agriculture Org., 52p.

15. Dansi A, Dantsey-Barry H, Agre AP, DossouAminon I, Assogba P, Loko YL, N'Kpenu EK, Kombaté K, Dansi M, Vodouhè R. (2013). Production constraints and farmers' cultivar preference criteria of cultivated yams (Dioscorea cayenensis - D. rotundata complex) in Togo. International Journal of Applied Biology and Pharmaceutical Technology, 4(2): 191-199.

16. Degras L (1986). L'igname. Techniques agricoles et productions tropicales. Maisonneuve et Larose, ACCT, Paris, France, 408 p.

17. Dibi KEB, Kouakou AM, Yeo TJ, Fofana I, N'zué B and Brou CY (2014). Effects of Planting Modes on Yam (Dioscorea rotundata, Poir and Dioscorea Alata L) Vine Cuttings for Mini Tubers Production, Int. j. sci. 11(2014):1. Vol.3, October 2014. 1-8.

18. Diby LN, Crasky R, Tie TB and Girardin O (2012). Understanding soil factors limiting the potential yield ofyam (Dioscorea spp.). 2012. http://www.cropscience.org.au/icsc2004/poster/2/3/322_dibyl.htm. 
19. Diby LN, Hgaza VK, Tie TB and Assa A (2009). Productivity of yams (Dioscorea spp.) as affected by soil fertility. Journal of Animal \& Plant Sciences. 5 (2), 494-506.

20. Doumbia $S$ (1998). Les systèmes de culture à base de plantes à racines et tubercules : cas de l'igname. AISA Développement. Revue Technique d'informations agricoles de l'Association des Sciences Agronomiques, nº, février 98, pp. 285 - 290.

21. Doumbia S, Toure M and Mahyao A, (2006). Commercialisation de l'igname en Côte d'Ivoire : état actuel et perspectives d'évolution, Cahier Agriculture, 2006, Vol. 15, N 3, p 273 - 276.

22. Dumont R (1997). La production d'ignames dans un village bariba du Bénin septentrional. Les Cahiers de la Recherche Développement $43:$ : 35-51.

23. Ehounou Jean-Noel (2014). Impact de la variabilité des saisons de pluies sur les besoins en eau de l'igname, du manioc et du maïs dans la région centre de la Côte d'Ivoire. Mémoire de Master2 de Sciences de la Terre Option : Hydrogéologie. UFR des Sciences de la Terre et des Ressources Minières, Département des Sciences et Techniques de l'Eau et du Génie de l'Environnement, Université Félix Houphouet Boigny, Abidjan-Côte d'Ivoire, $110 \mathrm{p}$.

24. Ettien JB, Tschannen AB, Nindjin C, Asiedu R, Assa A and Girardin O (2003). Evaluation de nouvelles variétés de d'igname en Côte d'Ivoire : Bilan de trois années d'expérience avec des génotypes améliorés par l'IITA. Agronomie Africaine Numéro spécial (4): 109116.

25. FAO (1997). Report on the inter-center review of root and tuber crops research in the CGIAR. Rome: Food and Agriculture Organization (FAO), Consultative Group on International Agricultural Research, Technical Advisory Committee (TAC), $115 \mathrm{p}$.

26. FAO (1999). Culture et utilisation de l'igname pour assurer pour assurer la sécurité alimentaire, texte de référence, 1999, « http // www.fao.org » consulté le 10 juin 2015.

27. Faostat (2019). Food and Agriculture Organization of the United Nations, 2019. Production: crops. Available at: http://faostat.fao.org/

28. Ferraton N, Cochet $\mathrm{H}$ and Bainville S (2002). Initiation à une démarche de dialogue. Étude des systèmes de production dans deux villages de l'ancienne boucle du cacao (Côte d'Ivoire). GRET (ed.), Paris. 134 p.

29. Floquet AB, Maliki R, Tossou RC and Tokpa C (2012). Évolution des systèmes de production de l'igname dans la zone soudano-guinéenne du Bénin. Cahiers Agricultures. 21 (6),427-437. 
30. Ghosh C and Woolridge JR (1988). An analysis of shareholder reaction to dividend cuts and omissions. Journal of financial research, 11(4), 281-294. Doi:10.1111/j.1475-6803.1988.tb00089.x

31. Goudou-sinha C. (1995). La mosaïque de l'igname: aspects épidémiologiques au Burkina Faso et variabilité du virus. [Online]. Montpellier, USTL. France. Available from: http://www.documentation.ird.fr/hor/fdi:41267 [Accessed: 21 February 2016]

32. Hgaza VK, diby LN, oberson A and Tschannen A (2012). Nitrogen Use by Yam as Affected by Mineral Fertilizer Application. Agronomy Journal. [Online] 104 (6), 1558.

33. Ike PC and Inoni EOE (2006). Determinants of yam production and economic efficiency among small-holder farmers in Southeastern Nigeria. J. Cent. Eur. Agric. 7, 337-342.

34. Jouve $\mathrm{P}$ (1992). Le diagnostic du milieu rural de la région à la parcelle : approche systémique des modes d'exploitation du milieu. In Mercoiret M. R. (Ed.) L'appui aux producteurs : démarches, outils, domaines d'intervention . Paris: Ministère de la coopération et du développement.

35. Kalms JM and Chabalier PF (1981). Bilan d'un essai agronomique de longue durée ; systèmes culturaux de Bouaké ; synthèse des principaux résultats de 1967 à 1978 d'un test de différents systèmes culturaux. IDESSA/DCV, Bouaké, Côte d'Ivoire 91 p.

36. Koné B (2007). La couleur comme indicateur de la fertilité des sols : utilisation des données pour l'étude de la fertilité potentielle des sols ferrallitiques au-dessus de la latitude 7 degrés Nord de la Côte d'Ivoire. Thèse de l'université de Cocody, Abidjan, $146 \mathrm{p}$.

37. Kone B and Assa A (2008). Utilisation des données pour l'évaluation de l'hétérogénéité des sols ferralitiques par la couleur selon le code munsell, Agronomie Africaine 20 (2) : 179 - 190

38. Kouakou AM (2010). Diversité génétique des ignames Dioscorea alata L. (Dioscoreaceae) en Côte d'Ivoire. Thèse de Doctorat Unique de l’Université de Cocody-Abidjan, Spécialité Génétique, Option Amélioration des Productions Végétales, UFR Biosciences, 118 p.

39. Kouakou AM, Dibi KEB, N'zue B, Essis BS and Zohouri GP (2015). Dichotomous key determining varietal groups of yam species Dioscorea alata L. Greener Journal of Agricultural Sciences, Vol. 5 (5), pp. 190-203, September 2015.ISSN: 2276-7770

40. Kouakou AM, Zohouri GP, Dibi KEB, N'zue B and Foua B (2012). Emergence d'une nouvelle variété d'igname de l'espèce Dioscorea alata L., la C18, en Côte d'Ivoire. Journal of Applied sciences 57: 41514158. ISSN 1997-5902. 
41. Kowal JM and Kassam AH (1978). Agricultural ecology of savanna: A case study of West Africa. Oxford: Oxford University Press.

42. Le Buanec B and Jacob B (1981). Dix-sept ans de culture motorisée sur un bassin versant du centre Côte d'Ivoire : évolution des sols et des rendements. Agronomie Tropicale, 36 (3), 203-211. ISSN 0151-1238

43. Lebot V (2009). Tropical root and tuber crops: cassava, sweet potato, yams and aroids. Crop production science in horticulture series 17. Wallingford, UK; Cambridge, MA, CAB!. 413p.

44. Maliki R (2006). Yam based sedentary cropping system and sustainable natural resources management in the central part of the Benin: Participatory development, constraints, adoption and diffusion of technologies. M.Sc. Thesis, Abomey-Calavi, University of Abomey-Calavai.

45. Moreau R (1990). Variations spatiales d'une couverture pédologique relativement homogène et expérimentation agronomique en basse Côte d'Ivoire. ORSTOM Fond Documentaire, $N^{\mathrm{o}}$ 27137, Land development-Management of acid soils : 163 - 173.

46. Mutsaers, H. J. W., Weber, G. K., Walker, P., \& Fisher, N. M. (1997). A field guide for on farm experimentation. International Institute for Tropical Agriculture (IITA)/CTA/ISNAR, 235 pp.

47. N'goran KE, Zohouri PG, Yoro RG, Kouakou MA, Assa A and Asiedu R (2007). Revue bibliographique sur la gestion de la fertilité des sols cultives en igname en Côte d'Ivoire, Agronomie Africaine 19 (3) : 281 - 288 (2007)

48. Ndabalishye Ildefonse (1995). Agriculture vivrière Ouest-africaine à travers le cas de la Côte d'Ivoire, Bouaké, Institut des savanes, 383p.

49. Nkonya E, Kaizzi C, Pender J. (2005). Determinants of nutrient balances in a maize farming system in eastern Uganda. Agricultural Systems. 2005;85(2):155-182. [Google Scholar]

50. Nweke, F., Ugwu, B., Asadu, C. \& Ay, P. (1991). Production costs in the yam-based cropping systems of southeastern Nigeria. RCMP research monograph, No. 6. Ibadan, Nigeria: IITA, 29p.

51. O'sullivan JN, Ernest J, Melteras M, Halavatau S, Holzknecht P and Risimeri J (2008). Yam nutrition and soil fertility management in the Pacific. Project final report. Aust. Ctr. Int. Agric. Res., Canberra, ACT, Australia.

52. Orkwor GC and Asadu CL (1998). Agronomy. In Food yams: Advances in research. Eds. NRCRI/IITA, Nigeria, pp. 105-141.

53. O'Sullivan and Jane Nancy (2010). Yam nutrition nutrient disorders and soif fertility management. [Online]. Canberra, A.e.T., Australian Centre for International Agricultural Research. Available from: 
http://search.ebscohost.com/login. aspx ?direct=true\&scope=site $\& d b=$ nlebk\&db=nlabk\&AN=437185 [Accessed: 6 January 2016].

54. Pieri C (1989). Fertilité des terres de savanes. Bilan de trente ans de recherche et de développement agricoles au Sud du Sahara Montpellier : CIRAD-IRAT, $444 \mathrm{p}$.

55. Richard C, Delphin O. and Houedjissin K (2010). Etat des lieux de la recherche sur l'igname au Bénin. [Online]. 71p. Available from: http://www.formadenvironnement.org/vie_Rapport_Igname\%20IITA 2010.pdf.

56. Samake O, Smaling EMA, Kropff MJ, Stomph TJ and Kodio A (2005). Effects of cultivation practices on spatial variation of soil fertility and millet yields in the Sahel of Mali. Agric. Ecosyst. Environ. 109, 335345.

57. Sanchez PA, Villachica JH and DE Band (1983). Soil fertility dynamics after clearing a tropical rain forest in Peru. Soil. Sci. Amer. J. $47: 1171$ - 1178. )

58. Seubert CE, Sanchez PA and Valverde C (1977). Effects of land clearing methods on soil properties and crop performance in Ultisol of the Amazon Jungle of Peru.Trop. Agr. 54 : 307 - 321.

59. Sinsin, B. et Kampmann, D. (2010). Atlas de la biodiversité de l'Afrique de l'ouest, Tome I : Bénin. Cotonou et frankfurt/Main. BIOTA, $676 \mathrm{p}$.

60. Sunanda T. W, Naser A. R. (2016). Marascuilo method of multiple comparaisons (an analytical study of caesarean section delivery). International Jounal of Contemporary Medical Researc 2016, 3(4):1137-1140.

61. Tittonell, P., Vanlauwe, B., De Ridder, N., Giller, K.E. (2007). Heterogeneity of crop productivity and resource use efficiency within smallholder Kenyan farms: soil fertility gradients or management intensity gradients? Agric. Syst. 94, 376-390.

62. Vauclin M and Chopart JL (1991). Méthodologie d'analyse de la variabilité spatiale de dispositifs agronomiques. In : AUPELFUREF (Eds.). Utilisation rationnelle de l'eau des petits basins versants en zone aride. John Libbey Eurotext, Paris : pp 307 - 315 ).

63. Vernier P and Dumont R (1998). La production et l'utilisation de cossettes d'ignames (Dioscorea cayenensis-rotundata) au Benin : situation actuelle et perspective. Proceedings of the 6th triennal symposium of the international society for tropical

64. Yeboua K (1990). Système d'assolement et de rotation culturale en milieu paysan dans le Sud-Est ivoirien. Compte rendu du séminaire national sur l'igname. 28 au 30 novembre 1990. Abidjan, Côte d'Ivoire: 35 - 38 . 